\title{
Institutional Factors Affecting Farmers' Decision to Adapt to Climate Change
}

\author{
Mpho Tshikororo ${ }^{1}$, Phineas Khazamula Chauke ${ }^{1} \&$ Jethro Zuwarimwe ${ }^{2}$ \\ ${ }^{1}$ School of Agriculture, Department of Agricultural Economics and Agribusiness, University of Venda, South \\ Africa \\ ${ }^{2}$ School of Agriculture, Institute of Rural Development, University of Venda, South Africa \\ Correspondence: Mpho Tshikororo, School of Agriculture, Department of Agricultural Economics and \\ Agribusiness, University of Venda, Private Bag X 5050, Thohoyandou 0950; Limpopo, South Africa. Tel: \\ 27-15962-8712. E-mail: mpho.tshikororo@univen.ac.za
}

Received: May 12, 2020

doi:10.5539/jas.v12n10p50
Accepted: August 9, 2020

Online Published: September 15, 2020

URL: https://doi.org/10.5539/jas.v12n10p50

\begin{abstract}
Adaptation to climate change has become the global focal point especially in recent years. Researchers have defined adaptation to climate change as an effective way for farmers to survive in the face of the scourge. This paper investigated how institutional factors plays a role in farmers' decision to adapt to climate change. The population of the study was emerging farmers drawn from five districts of the Limpopo province of South Africa The study used a two-stage cluster sampling technique to select a sample size of 206 emerging farmers. The dependent variable of the study was farmers' decision to adapt to climate change while the explanatory variables consisted of institutional factors such as access to extension services, farmers' organisation, membership and access to climate change information. Binary Logistic Regression model was used to determine emerging farmers' decision to adapt to climate change in Limpopo province. The results showed that institutional factors such as access to both weather information and extension services together with special training on climate change adaptation significantly influenced farmers' decision to adapt. Therefore, the study recommended participation of different stakeholders to provide institutional support to farmers and thus enhance their extent to adaptation.
\end{abstract}

Keywords: access, adaptation, binary logistic, climate change, decision, institutional factors

\section{Introduction}

Climate change has been proven to have negative impacts on agricultural productivity. As such the sector is regarded as the major contributor towards the scourge (Pye-Smith, 2011). Several studies have noted that climate change results in low agricultural production and increased food insecurity (Pereira et al., 2014; Maponya et al., 2013). Nwachukwu and Shisanya (2017) predicted that climate change has the potential to significantly decrease agricultural productivity in Africa. To mitigate for the above farmers are expected to modify their agricultural practices in order to align their methods of production with increasing challenges of climate change which directly affect agricultural activities (FAO, 2010). Due to the importance of adaptation as a critical and practical strategy to control the impacts of climate change and it becomes imperative for all stakeholders involved in food production to understand the various factors that shape farmers' decision to adapt to climate change (Jha \& Gupta, 2016). Support provided by national and international institutions to reduce the impacts of climate change has been found to positively influence farmers' adaptation (Comoé \& Siegristet, 2015). The process requires application of different practices that may include infrastructure, information and technological enhancement (IPCC, 2011). Various institutional factors significantly form part of climate change adaptive strategies particularly in developing countries (Juana et al., 2013). A study conducted by Bryan et al. (2009) in South Africa and Ethiopia on adaptation to climate change revealed that factors influencing farmers' decision to adapt to climate change were access to climate information, extension services and credit. Factors such as food aid provision, access to land and extension services were found to facilitate farmers' adaptation to climate change among the poorest farmers (Bryan et al., 2009). For successful achievement of climate change adaptation there is a need to have an in-depth understanding of different factors that shape farmers' agricultural practices and their 
adaptive responses to such stimulus (Nguyen et al., 2016). This paper investigated institutional factors affecting farmers' decisions to adapt to climate change in Limpopo Province of South Africa.

\section{Material and Method}

\subsection{Study Area}

The study was carried out in Limpopo province the 5th biggest in South Africa. It is located in the northernmost part of the country and covers an area of about $125,754 \mathrm{~km} 2$; with the latest population census of about 5,726,800 people (Statistics South Africa, 2015). More than 45\% of the R2-billion annual turnover of the Johannesburg Fresh Produce Market comes from Limpopo province. The province has an abundance of agricultural resources. It is one of the country's prime agricultural regions well-known for its production of livestock, fruits, vegetables, cereals and tea (LTA, 2014).

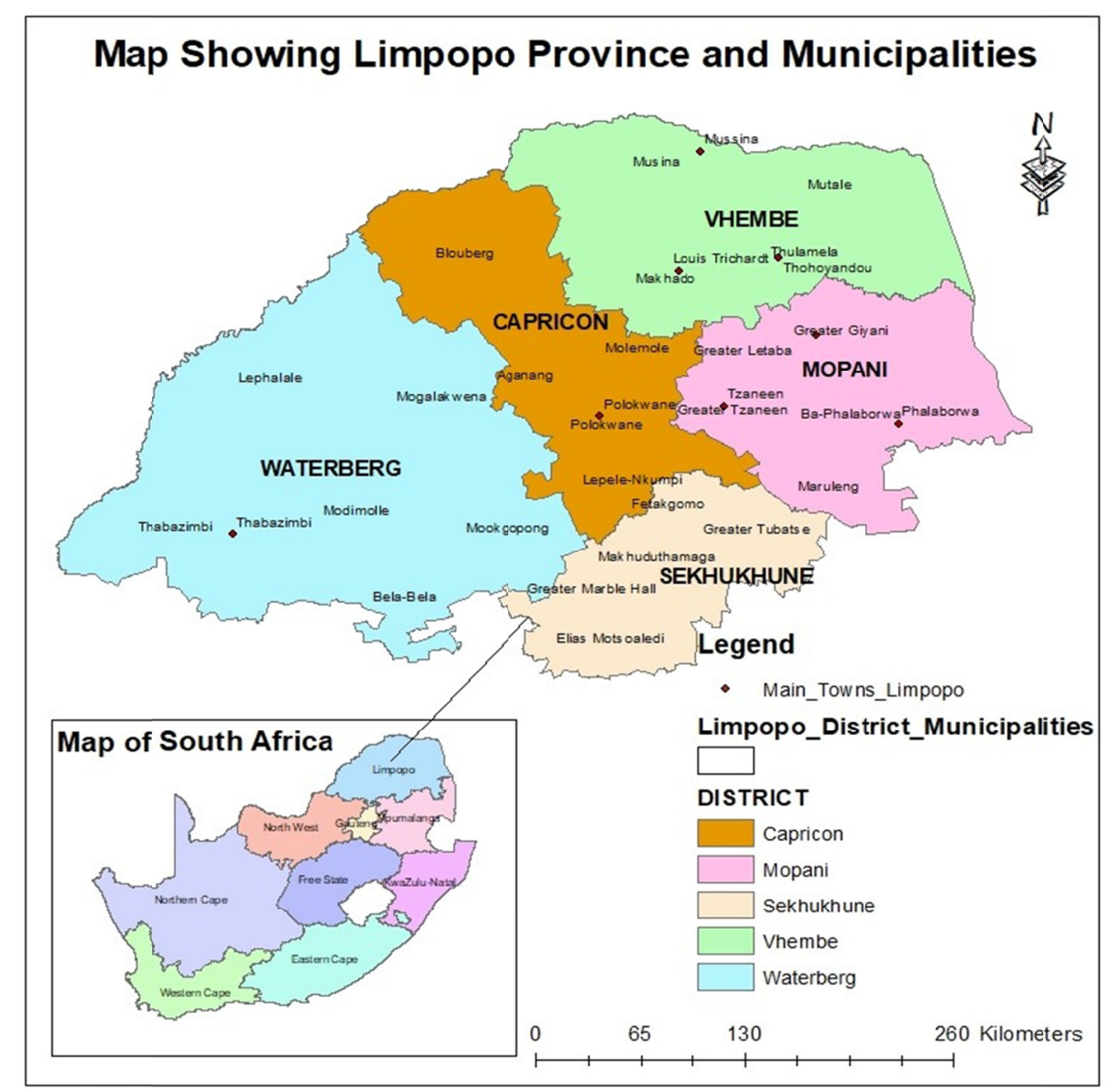

Figure 1. Map showing Limpopo Province and Local Municipalities

\subsection{Sampling Technique and Data Collection}

The population of the study were black emerging farmers in Limpopo province who benefitted from the land reform programme, and subsistence farmers striving to enter into the commercial farming sector, especially extensive livestock and crop production. Within the context of the definition of the emerging farmers it is next to impossible to have an accurate census of these farmers as there are no records of those who are transitioning from subsistence to commercial farming. In this paper the crop/livestock commercialization index (CCI) categorization developed by Zantsi, Greyling, and Vink (2019) was used to characterize the emerging farmers using Crop/Livestock Commercialization Indices of 0.5 and 0.66 to screen and define the population of the study. A multi stage sampling process was used to select participating farmers. Firstly purposive identification of 550 farmers whose production focus was partly for household consumption and partly for commercial market were identified across the province. To the census of 550 farmers a questionnaire was administered in face to face interviews. The farmers were clustered according the Province's District Municipalities. After administering the 
questionnaire to 550 farmers the CCI Indices of 0.5 and 0.6 was used to select 206 respondents whose responses qualified them to be characterized as emerging farmers. It is these 206 farmers whose data was then analysed in this paper.

\subsection{Empirical Model}

The Binary Logistic Regression Model (BLRM) was used to determine institutional factors that influence farmers' decision to adapt to climate change. BLRM is considered useful for situations in which the prediction of the presence or absence of a characteristic or outcome based on values of a set of predictor variables is required (Norusis, 2004). The BLRM is similar to a linear regression model but is suited to models where the dependent variable is dichotomous as in this study. BLRM coefficients were used to estimate odd ratios for each of the independent variables in the model. In the BLRM, the relationship between the dependent variable $Z$ and the probability of the event of interest is described by the following link function (Norusis, 2004):

$$
\pi_{i}=\frac{e^{z_{i}}}{1+e^{z_{i}}}=\frac{1}{1+e^{z_{i}}}=\frac{1}{1+e^{-z_{i}}}
$$

or,

$$
Z_{i}=\log \left(\frac{\pi_{i}}{1-\pi_{i}}\right)
$$

Where, $\pi_{i}=$ probability of the $i^{\text {th }}$ case; $Z_{i}=$ value of the independent variable for the $i^{\text {th }}$ case. The model assumes that $\mathrm{Z}$ is linearly related to the predictors.

Thus,

$$
\mathrm{Z}_{\mathrm{i}}=\mathrm{b}_{\mathrm{o}}+\mathrm{b}_{1} \mathrm{X}_{\mathrm{i} 1}+\mathrm{b}_{2} \mathrm{X}_{\mathrm{i} 2}+\ldots+\mathrm{b}_{\mathrm{p}} \mathrm{X}_{\mathrm{ip}}
$$

Where, $\mathrm{X}_{\mathrm{ij}}=$ predictor for the $j^{\text {th }}$ case; $\mathrm{b}_{\mathrm{j}}=j^{\text {th }}$ coefficient and $p=$ number of predictors. Since $\mathrm{Z}$ is unobservable, the predictors are related to the probability of interest by substituting $\mathrm{Z}$ in Equation 1.

$$
\pi_{i}=\frac{e^{z_{i}}}{1+e^{z_{i}}}=\frac{1}{1+e^{z_{i}}}=\frac{1}{1+e^{-\left(b_{0}+b_{i 1} X+\ldots+b_{p} X_{p}\right)}}
$$

The regression coefficients in the above expression were estimated through an iterative maximum likelihood method using SPSS V.25 (Hosmer \& Lesmeshow, 2000). In the regression context, it is assumed that there is a set of predictor variables, $\mathrm{X}_{1}, \ldots \mathrm{X}_{\mathrm{k}}$, that are related to $\mathrm{Y}$ and, therefore, provide additional information for predicting Y (Greene, 2003).

$$
\operatorname{Logit}\left(\mathrm{P}_{\mathrm{i}}\right)=\ln \left(\mathrm{P}_{\mathrm{i}} / 1-\mathrm{P}_{\mathrm{i}}\right)=\alpha+\beta_{1} \mathrm{X}_{1}+\ldots+\beta_{\mathrm{n}} \mathrm{X}_{\mathrm{n}}+\mathrm{U}_{\mathrm{t}}
$$

Where,

$\ln \left(\mathrm{P}_{\mathrm{i}} / 1-\mathrm{P}_{\mathrm{i}}\right)=$ logit for farmers' decision to adapt to climate change $\left(\right.$ Yes or No); $\mathrm{P}_{\mathrm{i}}=$ Yes; $1-\mathrm{P}_{\mathrm{i}}=$ No; $\beta=$ coefficient; $\mathrm{X}_{\mathrm{i}}=$ covariates; ${ }_{\mathrm{t}}=$ error term.

When the variables are fitted into the model in Equation 5, the model is presented as:

$$
\ln \left(\mathrm{P}_{\mathrm{i}} / 1-\mathrm{P}_{\mathrm{i}}\right)=\alpha+\beta_{1} \mathrm{X}_{1}+\beta_{2} \mathrm{X}_{2}+\beta_{3} \mathrm{X}_{3}+\beta_{4} \mathrm{X}_{4} \ldots .+\mathrm{U}_{\mathrm{t}}
$$

The estimated model was specified as:

$$
\begin{aligned}
\mathrm{Y}= & \alpha+\beta_{1} \mathrm{RWI}+\beta_{2} \mathrm{RI}+\beta_{3} \mathrm{SWI}+\beta_{4} \mathrm{CCC}+\beta_{5} \mathrm{RIS}+\beta_{6} \mathrm{SS}+\beta_{7} \mathrm{TSR} \\
& +\beta_{8} \mathrm{FO}+\beta_{9} \mathrm{AES}+\beta_{10} \mathrm{HRES}+\beta_{11} \mathrm{KES}+\beta_{12} \mathrm{CCST}
\end{aligned}
$$


Table 1. Description of dependent and explanatory variables

\begin{tabular}{|c|c|c|c|}
\hline Variable & Name description & Type of measure & Expected sign \\
\hline $\mathrm{D}$ & Decision to adapt & Yes $=0$, No $=1$ & \\
\hline RWI & Receive weather information & Dummy; Yes $=0$, No $=1$ & + \\
\hline RI & Receive information & Daily $=0$, Weekly $=1$, Bi-weekly $=2$, Monthly $=3$ & $-/+$ \\
\hline SWI & Source of weather information & Radio stations $=0$, Newspapers $=1$, Television $=2$, Colleagues $=3$, Extension agent $=4$ & + \\
\hline $\mathrm{CCC}$ & Climate change campaign & Dummy; Yes $=0$, No $=1$ & + \\
\hline RIS & Receive institutional support & Dummy; Yes $=0$, No $=1$ & + \\
\hline SS & Support source & Dummy; Government $=0$, Private institution $=1$ & $-/+$ \\
\hline TSR & Type of support received & Inputs provision $=0$, Training $=1$, Formal credit $=2$, Financial assistance $=3$ & $-/+$ \\
\hline FO & Farmers' organisation & Dummy; Yes $=0$, No $=1$ & $-/+$ \\
\hline AES & Access to extension services & Dummy; Yes $=0$, No $=1$ & + \\
\hline HRES & How to receive extension service & Face to face $=0$, Workshop $=1$, Telephonic $=2$, Consultation $=3$, Farm visit $=4$ & $-/+$ \\
\hline KES & Kinds of extension service & Advice on production $=0$, Climate change $=1$, Advice on marketing $=2$, Other services $=3$ & $-/+$ \\
\hline CCST & Climate change special trainings & Dummy; Yes $=0$, No $=1$ & $-/+$ \\
\hline
\end{tabular}

\section{Results}

Table 2 presents the results of the estimated model. The model classified rates of $88 \%$ for no adaptation, $90.6 \%$ for adaptation and an overall classification rate of $89.3 \%$. These results indicate the degree of accuracy of the model and therefore, the reliability of the resulting estimated coefficients with their accompanying statistics. From the data, the dependent variable would explain between $59.3 \%$ and $75.4 \%$ of the variation in results as indicated by the diagnostics. The non-significance of the goodness of fit indicates that the model fits the data well (Spicer, 2004).

Table 2. Parameter estimates of the binary logistic model of climate change adaptation

\begin{tabular}{|c|c|c|c|c|c|c|}
\hline Variables & B & S.E. & Wald & df & Sig. & $\operatorname{Exp}(B)$ \\
\hline RWI & 0.934 & 0.486 & 3.686 & 1 & $0.055^{*}$ & 2.543 \\
\hline RI & 0.179 & 0.218 & 0.668 & 1 & 0.414 & 1.195 \\
\hline SWI & 0.196 & 0.125 & 2.480 & 1 & 0.115 & 1.217 \\
\hline $\mathrm{CCC}$ & -0.018 & 0.465 & 0.002 & 1 & 0.969 & 0.982 \\
\hline RIS & 1.154 & 0.434 & 7.060 & 1 & $0.008 * * *$ & 3.170 \\
\hline SS & 1.268 & 0.688 & 3.397 & 1 & $0.065^{*}$ & 3.553 \\
\hline TSR & 0.141 & 0.116 & 1.464 & 1 & 0.226 & 1.151 \\
\hline FO & -0.131 & 0.460 & 0.082 & 1 & 0.775 & 0.877 \\
\hline AES & 0.528 & 0.485 & 1.187 & 1 & 0.276 & 1.696 \\
\hline HRES & -0.114 & 0.138 & 0.685 & 1 & 0.408 & 0.892 \\
\hline KES & 0.307 & 0.116 & 7.034 & 1 & $0.008 * * *$ & 1.359 \\
\hline CCST & -1.260 & 0.758 & 2.765 & 1 & $0.096^{*}$ & 0.284 \\
\hline Constant & -1.540 & 0.831 & 3.437 & 1 & 0.064 & 0.214 \\
\hline \multicolumn{2}{|l|}{ Diagnostics: } & \multicolumn{3}{|c|}{ Classification: } & \multicolumn{2}{|c|}{ Goodness of fit: } \\
\hline \multicolumn{2}{|c|}{$-2 \log$ likelihood $=56.891$} & \multicolumn{2}{|c|}{ Adaptation $=90.6 \%$} & \multicolumn{3}{|c|}{$\chi^{2}=1.234$} \\
\hline \multicolumn{2}{|c|}{ Cox \& Snell $=0.593$} & \multicolumn{2}{|c|}{ No adaptation $=88 \%$} & \multicolumn{3}{|c|}{$\mathrm{df}=1$} \\
\hline \multicolumn{2}{|c|}{ Nagelkerke $=0.754$} & \multicolumn{2}{|c|}{ Overall $=89.3 \%$} & \multicolumn{3}{|c|}{ Sig. $=0.947$} \\
\hline
\end{tabular}

Note. $\mathrm{N}=206$; Dependent variable $=$ Decision to adapt; Yes $=0 ;$ No $=1 .{ }^{* * *}, * *, *$ Significant at $1 \%, 5 \%$, and $10 \%$ probability level, respectively.

Table 2 indicates that five independent variables influence farmers' decision to adapt to climate change significantly. Out of twelve independent variables used in the model, access to weather information, access to institutional support, source of support, kind of extension services received and access to training in climate change were statistically significant in adaptation to climate change. Accordingly access to variables such as weather information positively and significantly influence farmers' adaptation to climate change. A unit increase 
in accessing weather information would increase farmers' adaptation to climate change by 0.93 chances. The results shows that having access to institutional support $(\mathrm{P}<1 \%)$ was also a strong predictor of results. Having access to institutional support significantly influence farmers' decision to adapt to climate change in that a unit increase in access to the variable increases farmers' adaptation to climate change by 1.15 chances. Source of support from which farmers access various forms of support significantly influence farmers to adapt to climate change. Additional unitary sources of access increase farmers' chances of adapting to climate change by 1.12 probabilities. The type of extension services offered to farmers has a positive significant influence in farmers' adaptation to climate change. An increase in the unit of various types of support offered to farmers increases their chances to adapt to climate change by 0.31 chances.

\section{Discussion}

The study observed that access to weather information increases farmers' adaptation to climate change 0.93 times, implying that farmers who have access to climate change information such as daily weather forecast are in a better position to adapt to climate change. This finding is consistent with that of Khanal et al. (2018) who stated that farmers who frequently receive information on climate change are more inclined towards adaptation than their counterparts. The finding is also aligned to that of Mulwa et al. (2017) who observed that access to climate change information is a major driver of adaptation among farmers. Furthermore, a study conducted by Chete (2019) showed that having access to climate change information has a positive and significant influence on farmers' adoption to various climate change adaptive strategies. Mugagga et al. (2019) also noted that access to climate change information through extension agents enhances farmers' adaptation decisions. The study also uncovered the significance of institutional support in influencing farmers' adaptation to climate change. A unitary increase in accessing institutional support increases farmers' adaptation to climate change by 1.15 times. The finding is backed by the study conducted by Below et al. (2015) who revealed that provision of local agricultural support has a positive impact on farmers' response to taking up different climate change adaptive strategies. The latter finding is also consistent to that of Comoé et al. (2015) who stated that provision of farmers' support by national and international organizations to reduce the impacts of climate change positively influence their adaptive decisions. A recent study also shows that farmers with access to weather forecasting information adapt to climate change more readily compared to their counterparts (Abid et al., 2019). Farmers are however more willing to adapt in situations where sponsorship opportunities arise more than when they have to depend on their own financial resources (Tzemi et al., 2016). It was also noted by Abid et al. (2019) that farmers with access to institutional support such as agricultural information have a higher likelihood to adapt to climate change than farmers without information. A source of support has a positive and significant influence in farmers' decision to adapt to climate change. An increase in one unit of source of support increases farmers' adaptation to climate change by 1.27 chances. This results implies that having a secured source of support positively influence farmers' adaptation to climate change. The latter finding is similar to that of a study conducted by Ngigi et al. (2017) who revealed that a source and channel of climate information dissemination play a significant role various climate change adaptive strategies. In a study conducted by Shisanya and Mafongoya (2016), it was revealed that government's support on mitigating the impacts of climate change seems to play a significant and positive role in farmers' climate change adaptive decisions. Also the type of extension service received has a positive and significant influence on farmers' adaptation to climate change. An increase in a unit of the type of extension services received increases farmers' probabilities to adapt to climate change by 0.30 chances. This results implies that when farmers access different kinds of extension services their adaptation to climate change also increase. This is also supported by the study conducted by Mehar et al. (2016) which revealed that enough exposure to extension services and training seems to have a useful impact on decision to adapt to climate change and selection of relevant adaptive strategies. The findings of this study are also similar to a study that revealed that accessibility of extension service proves to be critical towards farmers' selection of adaptive strategies and their willingness to adapt to climate change (Khanal et al., 2018). Farmers who have consultations with extension staff adapt to climate change more than their counterparts (Mulinde et al., 2019). These findings are similar to that of Abid et al. (2019) who revealed that farmers who receive advisory services from public extension officials are adoptive of various climate change adaptive strategies.

\section{Conclusion and Policy Implication}

The findings above show that having access to institutional support positively influence farmers' adaptation to climate change. Furthermore adaptation to climate change is influenced by the framers ability to secure a source of support improves farmers' adaptation to climate change. Having access to different kinds of extension services positively influence farmers towards adaptation. The study recommends that farmers be linked with various sources of support in order to enhance their adaptation strategies. It also recommends for enhancement of climate 
change adaptation through provision of institutional support by various stakeholders. The study further recommends that various institutions provide timeous climate change data and to capacitate farmers through relevant training interventions that would promote wider adaptation and adoption of mitigation measures. Also, the study further recommends that timely daily weather information be disseminated to farmers as a strategy to sustain their adaptive levels.

\section{Acknowledgements}

Authors highly appreciate financial assistance received from the University of Venda Research and Publication Committee and National Research Foundation. Furthermore, authors would particularly like to thank all the 550 participants for their engagement in the study.

\section{References}

Abid, M., Scheffran, J., Schneider, U. A., \& Elahi, E. (2019). Farmer Perceptions of Climate Change, Observed Trends and Adaptation of Agriculture in Pakistan. Environmental Management, 63(1), 110-123. https://doi.org/10.1007/s00267-018-1113-7

Arunrat, N., Wang, C., Pumijumnong, N., Sereenonchai, S., \& Cai, W. (2017). Farmers' intention and decision to adapt to climate change: A case study in the Yom and Nan basins, Phichit province of Thailand. Journal of Cleaner Production, 143, 672-685. https://doi.org/10.1016/j.jclepro.2016.12.058

Below, T. B., Schmid, J. C., \& Sieber, S. (2015). Farmers' knowledge and perception of climatic risks and options for climate change adaptation: a case study from two Tanzanian villages. Regional Environmental Change, 15(7), 1169-1180. https://doi.org/10.1007/s10113-014-0620-1

Bryan, E., Deressa, T. T., Gbetibouo, G. A., \& Ringler, C. (2009). Adaptation to climate change in Ethiopia and South Africa: Options and constraints. Environmental Science \& Policy, 12(4), 413-426. https://doi.org/ 10.1016/j.envsci.2008.11.002

Chete, O. B. (2019). Factors influencing adaptation to climate change among smallholder farming communities in Nigeria. African Crop Science Journal, 27(1), 45-57. https://doi.org/10.4314/acsj.v27i1.4

Comoé, H., \& Siegrist, M. (2015). Relevant drivers of farmers' decision behaviour regarding their adaptation to climate change: A case study of two regions in Côte d'Ivoire. Mitigation and Adaptation Strategies for Global Change, 20(2), 179-199. https://doi.org/10.1007/s11027-013-9486-7

FAO. (2010). Climate Smart Agriculture; Policies, Practices and Financing for Food Security, Adaptation and Mitigation. Food and Agriculture Organization (FAO), Rome, Italy.

Greene, W. H. (2003). Econometric analysis. Pearson Education India.

Hosmer D. W., \& Lesmeshow, S. (2000). Applied Logistic Regression (2nd ed.). New York: Wiley. https://doi.org/10.1002/0471722146

IPCC. (2011). Managing the risks of extreme events and disasters to advance climate change adaptation: A special report on working group I and working group II of the intergovernmental panel on climate change. Retrieved August 2, 2016, from http://www.ipcc.ch/ipccreports/ar4-syr.htm

Jha, C. K., \& Gupta, V. (2016). Climate Change Adaptation in Indian Agriculture Assessing Farmers' Perception and Adaptive Choices. Climate Change Adaptation, Resilience and Hazards (pp. 275-288). Springer International Publishing. https://doi.org/10.1007/978-3-319-39880-8_17

Juana, J. S., Kahaka, Z., \& Okurut, F. N. (2013). Farmers' perceptions and adaptations to climate change in Sub-Sahara Africa: A synthesis of empirical studies and implications for public policy in African agriculture. Journal of Agricultural Science, 5(4), 121. https://doi.org/10.5539/jas.v5n4p121

Khanal, U., Wilson, C., Hoang, V. N., \& Lee, B. (2018). Farmers' adaptation to climate change, its determinants and impacts on rice yield in Nepal. Ecological Economics, 144, 139-147. https://doi.org/10.1016/j.ecolecon. 2017.08.006

Limpopo Travel Agency. (2014). Retrieved February 4, 2017, from http://www.golimpopo.com

Maponya, P., Mpandeli, S., \& Oduniyi, S. (2013). Climate change awareness in Mpumalanga province, South Africa. Journal of Agricultural Science, 5(10), 273. https://doi.org/10.5539/jas.v5n10p273

Mehar, M., Mittal, S., \& Prasad, N. (2016). Farmers coping strategies for climate shock: Is it differentiated by gender? Journal of Rural Studies, 44, 123-131. https://doi.org/10.1016/j.jrurstud.2016.01.001 
Mugagga, F., Elepu, J., Nimusiima, A., \& Bamutaze, Y. (2019). Institutional Determinants to Climate Variability Adaptation by Smallholder Irish Potato Farmers in Rubanda District, South Western Uganda. American Journal of Climate Change, 8(01), 77. https://doi.org/10.4236/ajcc.2019.81005

Mulinde, C., Majaliwa, J. G. M., Twinomuhangi, R., Mfitumukiza, D., Komutunga, E., Ampaire, E., ... Jassogne, L. (2019). Perceived climate risks and adaptation drivers in diverse coffee landscapes of Uganda. NJAS-Wageningen. Journal of Life Sciences, 88, 31-44. https://doi.org/10.1016/j.njas.2018.12.002

Mulwa, C., Marenya, P., \& Kassie, M. (2017). Response to climate risks among smallholder farmers in Malawi: A multivariate probit assessment of the role of information, household demographics, and farm characteristics. Climate Risk Management, 16, 208-221. https://doi.org/10.1016/j.crm.2017.01.002

Ngigi, M. W., Mueller, U., \& Birner, R. (2017). Gender differences in climate change adaptation strategies and participation in group-based approaches: An intra-household analysis from rural Kenya. Ecological Economics, 138, 99-108. https://doi.org/10.1016/j.ecolecon.2017.03.019

Nguyen, T. P. L., Seddaiu, G., Virdis, S. G. P., Tidore, C., Pasqui, M., \& Roggero, P. P. (2016). Perceiving to learn or learning to perceive? Understanding farmers' perceptions and adaptation to climate uncertainties. Agricultural Systems, 143, 205-216. https://doi.org/10.1016/j.agsy.2016.01.001

Norusis, M. J. (2004). Straight talk about data analysis and IBM SPSS statistics.

Nwachukwu, I., \& Shisanya, C. (2017). Determinants of Agricultural Production in Kenya under Climate Change. Open Access Library Journal, 4, 1-10. https://doi.org/10.4236/oalib.1103583

Pereira, L. M., Cuneo, C. N., \& Twine, W. C. (2014). Food and cash: Understanding the role of the retail sector in rural food security in South Africa. Food Security, 6, 339-357. https://doi.org/10.1007/s12571014-0349-1

Pye-Smith, C. (2011). Farming's climate-smart future: Placing agriculture at the heart of climate-change policy.

Shisanya, S., \& Mafongoya, P. (2016). Adaptation to climate change and the impacts on household food security among rural farmers in uMzinyathi District of Kwazulu-Natal, South Africa. Food Security, 1-12. https://doi.org/10.1007/s12571-016-0569-7

STATSSA (Statistics South Africa). (2015). First quarter publication. Retrieved February 6, 2017, from http://www.statssa.gov.za

Trinh, T. Q., Rañola Jr., R. F., Camacho, L. D., \& Simelton, E. (2018). Determinants of farmers' adaptation to climate change in agricultural production in the central region of Vietnam. Land Use Policy, 70, 224-231. https://doi.org/10.1016/j.landusepol.2017.10.023

Tzemi, D., Breen, J. P., \& Teagasc, E. P. A. (2016). Examining Irish farmers' awareness of climate change and the factors affecting the adoption of an advisory tool for the reduction of GHG emissions. 90th Annual Conference, April 4-6, 2016, Agricultural Economics Society, Warwick University, Coventry, UK.

Zantsi, S., Greyling, J. C., \& Vink, N. (2019). Towards a common understanding of 'emerging farmer' in a South African context using data from a survey of three district municipalities in the Eastern Cape Province. South African Journal of Agricultural Extension, 47(2), 81-93. https://doi.org/10.17159/2413-3221/2019/ $\mathrm{v} 47 \mathrm{n} 2 \mathrm{a} 505$

\section{Copyrights}

Copyright for this article is retained by the author(s), with first publication rights granted to the journal.

This is an open-access article distributed under the terms and conditions of the Creative Commons Attribution license (http://creativecommons.org/licenses/by/4.0/). 